\title{
The food regime in late colonial Philippines: Pathways of appropriation and unpaid work $^{\dagger}$
}

\author{
Alvin A. Camba \\ Department of Sociology, Johns Hopkins \\ University, Baltimore, MD, USA

\section{Correspondence} \\ Alvin A. Camba, Department of Sociology, \\ Johns Hopkins University, Baltimore, MD, \\ USA. \\ Email: acamba1@jhu.edu
}

\begin{abstract}
I argue that food regimes need to take into account the production relations of paid and unpaid work. As an angle of vision, I use the historical geography of late colonial Philippines (1901-1941) to show how paid and unpaid work in food production was not discrete and separated processes but rather conjoined moments of capital accumulation. The colonial regime-in this context, American colonial government, U.S. agribusinesses, and Filipino landed elites-utilized state power, customary land relations, and commodity-specific characteristics to appropriate vast amounts of unpaid work from agrarian classes of Philippine labour and draft animals towards the exploitation of commodified labour power. These processes not only produced considerable quantities of coconut and sugar products that were exported to the American consumer market, sold at cheaper prices, and contributed to the profitability of U.S. agribusiness elites but also allowed the colonial regime to efficiently expand commodity production across the islands. The more the American capitalists and Philippine elites invested in Philippine agriculture, the more they appropriated unpaid work from the agrarian classes of labour.
\end{abstract}

\section{KEYWORDS}

environmental sociology, food regimes, political economy of colonialism, U.S. empire, world ecology

\footnotetext{
${ }^{\dagger}$ Earlier versions of the paper were presented at the Eastern Sociological Society's (ESS) 2015 Annual Meeting in New York City, the American Sociological Association's (ASA) 2016 Annual Meeting in Seattle, and the Twentieth Century Seminar by Johns Hopkins University's History Department in 2017. I am especially grateful to Shirley Lung for her writing suggestions and to Jason W. Moore for his extensive theoretical comments on the initial draft of the manuscript. I am also thankful to the editors and anonymous reviewers of JOAC. Any mistakes in the manuscript are my own and not theirs.
} 


\section{1 | INTRODUCTION}

The concept of food regimes exposes us to the complex, systemic relations among food, capital, and global power. ${ }^{1}$ Although considerable research has expanded food regime's analytical sharpness and empirical utility, my paper seeks to bring the nexus of production relations to food regime studies. At its centre, food regime is centred on wage labour. Specifically, as Araghi (2003, p. 46) rightly argues, the global production of value comes from differential forms of labour as world historical expressions of capitalism. However, he fails to specify the precise relations of production in food regimes (Araghi, 2009, p. 115). I suggest that a world ecological understanding of capitalism, one that places the relationship between paid and unpaid work at the centre, can shed light on the structure that shape the relations of power, nature, and capital in the production of food.

I argue that food regimes need to take into account the production relations of paid and unpaid work. According to a world ecological framework, paid work depends on the exploitation of commodified labour power and the expansion of commodity relations through capitalization, whereas appropriation refers to the "those extra economic processes to identify, secure, and channel unpaid work outside the commodity system into the circuit of capital" (Moore, 2015, p. 17). Following a world ecology perspective, ${ }^{2}$ I forward that paid and unpaid work is not discrete and separated processes but instead conjoined moments of capital accumulation. Capitalists appropriate unpaid work, or the energy reproduced outside the circuits of capital, into the exploitation of commodified labour power. In this paper, I apply the concept of appropriation from a general systemic relation to particular processes that emerge through the web of life. I suggest that if exploitation "is premised on the generative practices," appropriation, conversely, transforms and develops as capitalism moves across people, places, and spaces.

By examining primary sources from the archives across the United States, ${ }^{3}$ I use the historical geography of late colonial Philippines (1901-1941) as an angle of vision to show how the colonial regime-in this context, the American colonial government, U.S. agribusinesses, and Filipino landed elites-utilized state power, customary land relations, and commodity specific characteristics to appropriate unpaid work from agrarian classes of Philippine labour. Directed towards rice, coconut, and sugar, the colonial regime appropriated an enormous amount of unpaid work that eventually limited the reproduction of agrarian classes outside commodity production. These processes, then, produced considerable coconut and sugar commodities that were exported to the American consumer market, sold at cheaper prices, and contributed to the profitability of U.S. agribusiness elites. As a result, the more that American and Philippine elites invested in Philippine agriculture, the more they needed, expanded, and appropriated unpaid work from the agrarian classes of labour.

\section{I PATHWAYS OF APPROPRIATION: STATE POWER, LAND ARRANGEMENTS, AND COMMODITIES}

To construct the theoretical framework, I modify aspects of world ecology's appropriation. Specifically, I suggest that we can move back and forth between a generalized and particular forms of appropriation. As capitalism emerges from the web of life, the temporal and geographic limits of appropriation in specific historical contexts come from the web of life. This formulation not only complements Moore's notion that capitalism transforms and emerges from nature

\footnotetext{
${ }^{1}$ Research has been carried on the international modes of regulation, world production and accumulation (see especially Burch \& Lawrence, 2005; Dunaway, 1994; Friedmann, 1982, 1993; Friedmann \& McMichael, 1989; Holt-Giménez \& Shattuck, 2009), the potential third food regime (Bonnano, Busch, Friedland, Gouveia, and Mingione, 1994; Campbell, 2009; Fold \& Pritchard, 2005; Pritchard, 1998), and peasant-based research (Holt-Giménez \& Patel, 2009).

${ }^{2}$ Many other works argued that capitalism needs to draw from the outside its confines to expand accumulation. The most notable example is Harvey's $(1990,1999)$ "Accumulation by Dispossession."

${ }^{3}$ The author gathered materials from the U.S. Library of Congress, the University of Michigan's "The United States and its Territories, 1870-1925: Age of Imperialism," and the "Philippine and National Archives" at the University of Maryland College Park.
} 
(Camba, 2015, p. 288; Moore, 2015, p. 18) but also moves us towards unravelling the question of production relations. In other words, it opens up various analytical lenses that capture the relations in between paid and unpaid work across specific historical moments.

The generalized form of appropriation is the systematic process that links the appropriation of unpaid work and the exploitation of commodified labour power in capitalism. From Luxemburg (1970, p. 30) to the Feminist Marxists (Federici, 2004, p. 75; Seccombe, 1974, p. 5), many have argued that unpaid work plays a pivotal role in capitalism (Mies, 1999, p. 115). Emerging from these theoretical perspectives, a world ecological framework suggests that the exploitation of commodified labour power not only depends upon but also demands the appropriation of unpaid work from nature. ${ }^{4}$ For Moore, abstract social labour is a substance of value, and the exploitation of labour power, which value directly derives from, crucially depends on the uneven appropriation of energy outside the circuits of capital. In this sense, the value and commodity relations are only a single moment of value relations, which also constitute portions of unpaid work within the reach of capitalist power. The other moment necessarily involves the appropriation of energy outside the circuits of capital, which is needed for the reproduction of commodified labour power. As appropriation funnels these work and energy into the exploitation of commodified labour power, the capacity of nature and human beings to reproduce outside the circuits of capital becomes weaker.

World ecology considers non-human entities and nature more broadly as sources of unpaid work: lands acquired for cheap, newly dispossessed indigenous groups, or indentured workers employed through informal means. Further illustrating the benefits of using non-wage labour as sources of unpaid work, Moore aptly notes that the "the whole of nature had to be put to work - in a radically alienating and dynamic way - for capitalism to survive" (Moore, 2017, p. 613). In contrast to conventional formulations, which posit conflates unpaid work and the exploitation of labour, world-ecology forwards that unpaid work is indispensable to the exploitation and reproduction of commodified labour power. Taken from this perspective, industrial production and factory farms cannot profit from lowered tariff rates or cheap labour alone; but through appropriation, also, capitalism requires vast land, healthy water bodies, and clean air. From this generalized moment of appropriation, I suggest that appropriation takes particularly distinct but overlapping forms: (a) state power or historically specific institutional structures; (b) customary land relations; and (c) commodity-specific characteristics rooted in particular geographies. ${ }^{5}$

First, state powers or, in this context, colonial governing structures and institutions exert differential processes and outcomes over the form of appropriation as well. Works on the colonial period ushered in notions of "colonial-diasporic," "neocolonial," and the "colonial division of labour," but such concepts make the colonizer's history alone the focal point of colonial regimes. We must also include the historically specific of character colonialisms, which include the colonizer's modes of governance and the colonized population's acts of resistance. Although debates on the "agrarian question" in the contemporary period have gained prominence in the food regime literature (e.g., Borras, McMichael, \& Scoones, 2010; McMichael, 2009), land-related colonial processes in the earlier periods have been generally overlooked. As Bernstein (2010, pp. 25-26) argues, capitalism is capable of exploiting different forms of labour through a variety of political arrangements. I further these initial formulations by suggesting that the colonial state also incorporates previously existing agrarian structures to appropriate unpaid work through state policies, economic strategies, and oppressive laws.

Second, unpaid work also emerges from customary land arrangements with distinct histories. Different political systems and cultural systems exert influence on land relations. In many parts of the world, a variety of customary land arrangements shape access to and use of land between classes and ethnicities. In this case of the colonial Philippines, the customary land arrangements pertain to the political systems with a plantation system of landlords and agrarian classes of labour. Landowners exercise customary powers through economic and extra-economic means of coercion:

\footnotetext{
${ }^{4}$ For some of World-Ecology's growing literature, see the following (Camba, 2015, Campbell \& Niblett, 2016, Dixon, 2015, Gill 2006, El-Khory 2016, Lohmann, 2006, Parenti 2014, Weis, 2013).

${ }^{5}$ I recognize that these pathways are products of the bundles of humans and extra-human relations. However, it is important to specify how appropriation moves back and forth between the general and particular.
} 
the power to banish, refusal to bestow legitimacy or blessing, and the right the use of land. Agrarian classes, as tenants and sharecroppers, have a variety of responsibilities, give-and-take practices with the landowners, and power relations formed during colonial and colonial time periods.

However, due to agrarian classes' incomplete access to land, they also depend on monetary payment and commodity production to subsist. Nevertheless, as Bernstein (2010, p. 106), even though agrarian classes of labour lack access to the means of production, they are not entirely dispossessed. As they receive a combination of money and crops as payments, wage payments often fall below the market rate. As work intensifies, payment remains the same. As a result, their uncompensated extra work constitutes the appropriated unpaid work. The reproduction of agrarian classes of labour-tenants and sharecroppers-gradually becomes more expensive within the commodity relation.

And lastly, unpaid work emerges from commodity-specific characteristics. In the colonial context, I argue that the use of draft animals should be constituted as a central feature of unpaid work in food regimes. Different works have categorized draft animals in the following ways: working class (e.g., Hribal, 2007, 2011), fixed capital, and also circulating capital. From the standpoint of capital, draft animals have been considered as fixed capital and circulating because, just like machines, they are purchased at the initial stages of production and constantly reused in the process. Although draft animals could not be considered part of the working class, ${ }^{6}$ they also do not neatly fit in the categories of fixed and circulating capital. Indeed, treating draft animals as circulating and fixed capital misses the production relations between agrarian classes of labour and draft animals as well as the unpaid work outside the circuits of capital.

Historically, the reproduction of draft animals occurred under the care of agrarian classes and nature. Draft animals have constructed dependent and intimate relations with humans, other animals, and nature, which capital does not remunerate in the production process. Although draft animals are mainly produced and exported for meat and milk production in contemporary times (Weis, 2007, p. 16; Weis, 2013, p. 34), their pre-existing and historical relations with agrarian classes and nature in general have evolved yet continued to remain outside the circuits of capital. Draft animals need agrarian classes of labour-feeding, sheltering, and cleaning-to facilitate their reproduction. In return, these animals have been central to the lives of the agrarian classes: They follow and know their caretakers; are cleaned and washed by peasants; provide milk and sustenance; and reproduce themselves through their relations with nature. Though these relations were central in various commodity systems-rice, salt, and other commodities-a broader system of capitalism has mobilized humans and animals for commodity production. Furthermore, the relations between draft animals, other entities (such as birds and insects), and nature more broadly-grasslands and sunlight for sustenance-also exist outside commodity production.

These relations produced various habitats, biological linkages, and behaviors that capital appropriates when necessary. Indeed, ploughing the soil, grazing the land, and provisioning the fertilizers add energy to food production without any additional cost. Capitalists arguably pay the agrarian classes at fixed rates, but portions of production and the reproduction costs of agrarian classes and draft animals remain unpaid. ${ }^{7}$ This nexus of paid and unpaid work adds energy to food production and ensures that partial to the full costs of reproduction goes unpaid, subsidizing the commodified labour power that colonial landowners and U.S. agribusinesses need to pay. In turn, the subsidized labour cost decreases the cost of production, enabling capitalists to profit immensely. As the following empirical narrative shows, the context of the U.S. colonial regime in the Philippines features a back and forth between a generalized and particular forms of appropriation. These particular forms of appropriation manifest through three pathways: state power, land arrangements, and commodity-specific characteristics.

\footnotetext{
${ }^{6}$ Some works seek to treat animals differently. Haraway (2007, pp. 5-6) examines the philosophical underpinnings of human-animal interaction. Similarly, Shukin $(2009$, p. 2) analyses how animals are represented and rendered by market logic for consumption.

${ }^{7}$ Before the mechanization of agricultural production in the post-war period (e.g., Patel, 2009, 2013), draft animals were widely used to do particular kinds of agriculture work. With the advent of mechanization and factory farming today, animals are mainly used for meat consumption (Weis, 2007).
} 


\section{3 | FROM THE FRIAR LANDS TO THE LANDLORDS}

The Philippines was a Spanish colony from the 16th century until the end of the 19th century. The Spanish colonial regime transformed heterogeneous land relations across the islands into several distinct arrangements: (a) the friar lands, which were granted to the various Catholic orders due to their role in Philippine colonization, that spanned from 4,000 to 20,000 ha; (b) the encomiendas, which were awarded to Spanish subjects, in exchange for their service to the crown in the 16th century to the 18 th century ${ }^{8}$; and (c) the pacto retroventa, which allowed Filipino and Chinese mestizo elites to own huge swaths of land for export production near the end of Spanish rule. Although friar lands and encomienda were the most dominant arrangements from the 16th century to the early 18th century, the pacto retroventa became more common with Spain's increasing need to bolster the colonial export economy in the middle of the 19th century.

Although historical sources give uneven and sometimes conflicting accounts about which forms of labour the three types of land arrangements employed (Scott, 1994), it is important to note that pre-existing communal relations changed alongside the land arrangements ${ }^{9}$ (Phelan, 1959, p. 23). In the Spanish period, landlord-peasant ties became more common across these land arrangements, including inherited servitude among others with varying levels of remuneration for workers (Camba, 2012). The most dominant one, called servicious personales (Cushner, 1976, p. 14; Owen, 1974, p. 311), mimicked quasi-feudal relations from medieval Spain that required landlords to become "godfathers" of peasant children, provide capital for religious gatherings, and provision emergency measures at the time of droughts and disasters (Owen, 1974, p. 312). These benefits, in turn, ensured tenant political and cultural (religious) loyalties. ${ }^{10}$

As the Americans took the colony from Spain in 1898, the new regime implemented laws that again changed land arrangements across the islands. In particular, the Philippine Act of 1902 enabled the colonial government to buy out and reallocate most of the friar lands to the Philippine elites. Having benefited from pacto retroventa as well as the encomienda during the earlier colonial period, elites were already medium- and large-sized landowners (Endriga, 1969). By the state power of the American colonial government, both friar lands and their workers were appropriated from the control of religious orders and then transferred to the Filipino elites. Most of the transferred workers were small farmers or tenants renting land from the friars (Census of the Philippine Islands, 1920, p. 45). The new American government, thus, allowed the Filipino elites to consolidate more land and workers in exchange for their political loyalty. In 1903, there were 815,453 farms of different sizes ranging from the smallest plots to the largest haciendas (Jakosalem \& Reyes, 1922, p. 21). Although the number of registered farms substantially increased in 1918, the number of landowners decreased by $30 \%$, implying a greater concentration of land in the hands of fewer owners (Jakosalem \& Reyes, 1922, p. 21).

Accompanying the appropriation of land, the American colonial regime invested an enormous amount of capital to improve agricultural production in the Philippines. In 1901, various laws and programmes were implemented to upgrade agricultural production. ${ }^{11}$ Unlike the large-scale plantation economy of Dutch Indonesia, the foundation of American rule in the Philippines was forged upon a partnership of necessity with Filipino elites. Because the Americans could not build mega large-scale plantations, they instituted a colonial state and Philippine elite partnership by giving loans to regional and provincial elites aimed at expanding rice supply and mechanizing cash crop production. In other words, the Americans controlled Philippine agriculture not by owning large plantations but through indirect long-term financing.

\footnotetext{
${ }^{8}$ See Camba (2012) and Phelen (1969) for a discussion of the encomienda.

${ }^{9}$ Although sources group indentured work, share tenants, and salaried workers as similar kinds of agrarian workers with analogous responsibilities to the landlord, sources also do not give enough information on the differences of their rights and responsibilities. It is reasonable to assume that there are differences, but these distinctions will not affect the paper's argument.

${ }^{10}$ Jocano speaks of these in his works, but Bankoff in "Cultures of Disaster" published in 2002 also elaborated these models.

${ }^{11}$ These laws pertain to Acts No. 1688, 1837, and 1854 (e.g., Philippine Commission, 1902a, p. 26).
} 
Although the Philippines was a self-sufficient rice-producing colony during the Spanish period, during the tumultuous years of the Philippine revolution (1896-1899), the islands needed to import $1 / 3$ of its rice supplies from China and Saigon (Peña, 1921, p. 141). Despite the rice deficit in the colony, Filipino elites wanted to shift from rice cultivation to cash crop production for the export market. Foreman (1906), an American travelling in the Philippines at the end of the 19th century, noted that "in recent years it has been more profitable to raise sugar and some other kinds of crops" (p. 360). Even though the area cultivated for rice was $94.5 \%$ of the combined total areas for all kinds of cash crops in 1901 (Census of the Philippine Islands, 1905a, p. 367), reducing rice production in favour of cash crops would have endangered American hold over the Philippines due to the potential food shortage and subsequent disorder. Identifying the irony of this situation, the U.S. Secretary of Interior remarked in 1902, "for a colony that mainly depended on agriculture, the Philippines still needed to import rice for its own needs" (Foreman 1905, p. 358). As a result, the severe rice deficits of early 20th-century Philippines continued to shape the form and extent of appropriation from that period onwards. The next section discusses how the colonial regime solved the problem of rice deficits by importing an enormous number of draft animals in order to expand rice production.

\section{I RICE SHORTAGE, AGRARIAN CLASSES OF LABOUR, AND DRAFT ANIMALS (1901-1920)}

Rice, the staple food in East-South-east Asia, coexisted with fishing and hunting, early industries of textiles, ceramics sectors, and commodity export regimes of mining and timber (Cushner, 1976, p. 14; Jocano, 1987). Reacting to the rice deficit, the colonial regime passed the burden of expanding the rice supply to the agrarian classes by increasing the amount of required produce. As rice supplies were needed to avoid societal unrest and political discord in the colony, the number of these workers-indentured workers and tenants-in the farms increased as friar lands were transferred from the religious orders to the hands of the Filipino elites (Endriga, 1969, p. 16). Wages paid to farm laborers vary regionally and range between US $\$ 0.15$ and US $\$ 0.30$ (Census of the Philippine Islands, $1905 \mathrm{~b}$, p. 427), and these rates were far lower than wages in the United States (Holmes, 1921, p. 34).

Rice production in the Philippines was directly linked to the carabao, a type of water buffalo, and other animals, which were necessary for ploughing, harrowing, and providing transportation. Because agrarian classes were mandated to use their own draft animal, or rent one from the landlord to produce the necessary output to pay the dues, the carabao, the most populous draft animal in the colony, was drawn into agriculture work (Philippine Commission, 1902b, p. 54). Despite the fact that landlords wanted to fully mechanize agricultural production, the cheaper cost and versatility of carabaos outweighed such desires. ${ }^{12}$ Because carabaos were stronger and could work longer than other draft animals (Carpenter, 1926, p. 90), it remained as the main draft animal of, and were cheaper than machines for, Philippine agriculture. ${ }^{13}$ As Table 1 shows, the growing population of imported carabaos occurred alongside the exploitation of agrarian classes. From 1900 to 1904, the rice imports of the colonial regime continued to increase. By 1905, the amount of rice imports decreased and stabilized due to the expansion of the carabao population in the fields. Although the yearly draft animal imports were small relative to the bigger pre-existing population in the colony (see Table 2), the additional livestock supplemented the labour for the rice production (Buencamino, 1926, p. 241).

\footnotetext{
${ }^{12}$ Even though the number of draft animals during the mid-19th century was unclear, thousands were killed or lost during the Philippine revolution in 1898. One estimate stated that there were only 500,000 carabaos, or water buffalos, 250,000 cattle, and 250,000 other animals in the Philippines when the Americans arrived (Governor General, 1903, 1908; Philippine Commission, 1902a). The draft animal population was considerable but needed to be supplemented by importing new stocks every year.

${ }^{13}$ Although many of these animals were imported for the meat, the market should not be exaggerated. The question of farm work and meat consumption should be instead analysed in a spectrum because in most cases, draft animals did both.
} 
TABLE 1 Rice imports and draft animals population from 1900 to 1907 in the Philippines

\begin{tabular}{lccc} 
Year & Value of imported rice in US\$ & Number of imported carabao & Carabao value in US\$ \\
1900 & $3,113,423$ & 4,555 & 129,476 \\
1901 & $5,490,958$ & 2,266 & 73,840 \\
1902 & $6,578,481$ & 15,435 & 481,846 \\
1903 & $10,061,323$ & 29,783 & 728,818 \\
1904 & $11,548,841$ & 35,828 & 834,560 \\
1905 & $7,456,738$ & 30,256 & 772,812 \\
1906 & $4,325,500$ & 30,729 & 828,206 \\
1907 & $3,662,493$ & 38,300 & $1,058,824$ \\
\hline
\end{tabular}

Source: Report of the Philippine Commission to the Secretary of War (Part 2; 1909, p. 586).

TABLE 2 Carabaos and cattle population in the Philippines, 1910-1918

\begin{tabular}{lrrr} 
Year & Carabaos & Other cattle & Value in US\$ \\
1910 & 756,724 & 269,963 & $\mathrm{n} / \mathrm{a}$ \\
1911 & 863,649 & 315,495 & $\mathrm{n} / \mathrm{a}$ \\
1912 & 958,512 & 362,230 & $\mathrm{n} / \mathrm{a}$ \\
1913 & $1,047,164$ & 418,114 & $\mathrm{n} / \mathrm{a}$ \\
1914 & $1,147,433$ & 477,736 & $\mathrm{n} / \mathrm{a}$ \\
1915 & $1,221,866$ & 534,106 & $\mathrm{n} / \mathrm{a}$ \\
1916 & $1,228,836$ & 566,199 & $74,831,364$ \\
1917 & $1,271,208$ & 602,756 & $82,410,606$ \\
\hline
\end{tabular}

Note. $\mathrm{n} / \mathrm{a}=$ not available.

Source: Wester (1920, p. 18).

As a labour-intensive crop, rice needed ploughed lands during the initial process of cultivation before seeding, disking, and harrowing. The work of carabaos was useful not only for these procedures ${ }^{14}$ but also for transporting the "carriage out of the mud in the provinces, where horses could get along no further" (Foreman, 1905, p. 337). Frank G. Carpenter, an American traveller in the 1920s, observed that "in vain for cows, sheep, or horses ... only animals visible are the carabaos, or water-buffalos" (Carpenter, 1926, p. 68). As Carpenter (1926) notes, "men usually ride their carabaos from fields to their homes, and I often see one in a pasture" (p. 68). These animals provided "carting, ploughing, carrying loads on its back, and almost all labour of the kind where great strength is required for a short time" (Foreman, 1905, p. 337). ${ }^{15}$

To some extent, carabao rearing and reproduction occurred outside the circuits of capital process, which subsidized the rice production process for the colonial regime. Foreman (1905, p. 391) noted that the carabao was "amphibious animal, and if left to itself would pass quite one-third of its life in water or mud, whilst it is indispensable to allow it to bathe everyday" (p. 337). Carpenter further remarked upon the affinity between the carabaos and the agrarian classes: "docile, slow in its movements, and easy to train.... It knows the voices of the family to which it belongs, and will approach or stand still when called by any one of them" (Carpenter, 1926, p. 69). He further observed that Philippine agrarian labour treated the carabaos "almost like one of the family" (Carpenter, 1926).

\footnotetext{
${ }^{14} \mathrm{~A}$ plough is attached to the draft animal.

${ }^{15}$ Although the carabao was used in all kinds of cash crop production, some parts of the colony relied on hemp cultivation, which was most profitable on highlands and did not need labour-intensive work of carabaos (Carpenter, 1926, p. 68).
} 
Eventually, the demand for and price of carabaos increased in the colony. Price increase not only refers to rising demand for carabao work but also indicates appropriation's impact on the reproduction cost of carabaos. In 1905 , carabaos cost US\$10 per head in the lowland plains (Copeland, 1908, p. 307), but in the swampy areas of sugar production, carabaos could cost as much as US $\$ 30$ per head (Carpenter, 1926, p. 85). By 1918, carabaos in the lowlands cost US\$18 per head, whereas carabaos in the swampy areas cost US\$45 per head (Carpenter, 1926, p. 87). Carpenter indicated that by the 1920 s, the number of carabaos in the colony multiplied immensely and became more expensive (Carpenter, 1926, p. 89). On average, carabaos have a total of 15 to 18 working years; the first 12 years represent the height of their productivity when they could undertake more strenuous work, whereas they would perform lighter labour during the last few years. Under conditions of overworking, carabaos likely last for 8 to 12 years.

As illustrated in Table 3, different kinds of draft animals were also used by the colonial government, kept and studied in colonial science stations, experimented and bred, and eventually domestically sold or loaned to large haciendas and medium-sized farms (Wester, 1905, p. 17). Horses and mules transported crops and other agricultural necessities (Moberly, 1907, p. 8) such as seeds, farming tools, machineries, wood, stone, metals, and many others. Goats and sheep grazed the land freely and continuously (Carpenter, 1926, p. 91). In most cases, these animals ploughed and tilled the land for 15 to 17 years. After their working years, most of these animals were sold to slaughterhouses or turned into meat for the family (The Philippine Agricultural Review, 1912, p. 467).

Thus, in the short span of 20 years, the American colonial regime transformed Philippine agriculture through the unpaid work of the agrarian classes of labour and draft animals. Specifically, the number of draft animals, the amount of rice, and land areas cultivated exponentially increased (see Table 4). ${ }^{16}$ In 1908, there were 795,000 carabao and cattle in the colony, which were utilized for meat consumption, agricultural cultivation, and milk production (The Philippine Agricultural Review, 1908a, p. 189). In 1918, over 2,078,649 draft animals with an estimated worth of US $\$ 3$ million worked for agricultural production of all crops in the Philippines (Wester, 1920, p. 18). ${ }^{17}$ The unpaid work of draft animals transformed the rice deficit to a surplus, stabilizing the colonial regime's political control and cash crop exports. From 1903 to 1924, rice production increased from an average of 1,484,895 to 1,737,910 hl annually. From 1907 to 1917, the revenues of the six most important crops in the Philippines, namely, rice, abaca, sugar, coconuts, corn, and tobacco, "jumped from previous high record of US\$120,500,000 for 1917 to US\$175,000,000 for 1918" (The Philippine Agricultural Review, 1919, p. 3). Between 1917 and 1918, the Philippine agriculture sector gained a net revenue of US\$54 million for 1 year, even higher than the average growth from the previous 5-year period (The Philippine Agricultural Review, 1919, p. 5). Because of this expansion, the colonial regime saw the enormous potential of the Philippines to take on a bigger role in the global food economy (Camus, 1921, p. 11). Indeed, the amount of land for cultivation correspondingly increase. Although rice production expanded, the American colonial regime simultaneously converted idle land into agricultural lands. In 1903, out of the 2.8 million ha, 29 million ha could be used for cultivation (Camus, 1921, p. 11). In 1918, agriculture land expanded to 3.7 million ha (Wester, 1920, p. 7).

Alongside importing draft animals, the colonial government also implemented other measures to increase rice production: experimenting on plants, mixing genetic seeds, training farmers, and building agricultural colonies (The Philippine Agricultural Review, 1919). Because rice production increased because of draft animals and agrarian workers, the demand for land also rose, which capital channeled in various ways-banking, government disbursement, loans, allocation of seeds, and credit associations-took advantage of and appropriated. Between 1917 and 1918 , the area for rice production increased "by 192,000 ha [hectares] in cultivation over the average of the previous five years, an increase in the yield of 1,202,000,000 liters, and an increase in value over the same period, of US\$37,000,044" (The Philippine Agricultural Review, 1919, pp. 3-4). In 1918, 1.3 million ha of land produced $2.6 \mathrm{billion}$ hl of rice valued at US\$67,581,685.5 (The Philippine Agricultural Review, 1919, p. 4). During this year, around $41.3 \%$ of the

\footnotetext{
${ }^{16}$ Despite dealing with rinderpest and various forms of diseases.

${ }^{17}$ One U.S. dollar in 2016 was worth US $\$ 23.65$ in 1915 (Eichengreen \& Flandreau, 2012). In this case, US\$375,000 is worth $\$$ US8.8 million in 2016.
} 
TABLE 3 Miscellaneous animal population in the Philippines, 1910-1918

\begin{tabular}{|c|c|c|c|}
\hline Year & Horses and mules & Sheep and goats & Value in US\$ \\
\hline 1910 & 142,604 & 535,621 & $\mathrm{n} / \mathrm{a}$ \\
\hline 1911 & 151,696 & 548,632 & $n / a$ \\
\hline 1912 & 170,861 & 574,450 & $\mathrm{n} / \mathrm{a}$ \\
\hline 1913 & 179,089 & 632,327 & $n / a$ \\
\hline 1914 & 215,826 & 710,052 & $\mathrm{n} / \mathrm{a}$ \\
\hline 1915 & 223,195 & 773,496 & $\mathrm{n} / \mathrm{a}$ \\
\hline 1916 & 203,430 & 803,245 & $26,838,473.5$ \\
\hline 1917 & 214,204 & 878,359 & $32,762,418$ \\
\hline 1918 & 234,125 & 906,768 & $\mathrm{n} / \mathrm{a}$ \\
\hline
\end{tabular}

Note. $\mathrm{n} / \mathrm{a}=$ not available.

Source: Wester (1920, p. 19).

TABLE 4 Rice cultivation and production in the Philippines, 1910-1918

\begin{tabular}{llcc} 
Year & Area under cultivation (ha) & Production of rice (hl) & Value in US\$ \\
\hline 1910 & $1,102,000$ & $14,144,214$ & $30,310,500$ \\
\hline 1911 & $1,044,000$ & $15,397,572$ & $32,996,000$ \\
\hline 1912 & $1,079,000$ & $8,716,851$ & $21,153,000$ \\
\hline 1913 & $1,141,000$ & $18,375,143$ & $30,868,500$ \\
\hline 1914 & $1,245,000$ & $17,052,610$ & $30,462,500$ \\
\hline 1915 & $1,131,000$ & $13,363,867$ & $26,039,500$ \\
\hline 1916 & $1,141,000$ & $15,659,148$ & $31,093,500$ \\
\hline 1917 & $1,226,000$ & $21,207,537$ & $40,689,000$ \\
\hline 1918 & $1,368,140$ & $26,846,284$ & $67,581,500$ \\
\hline
\end{tabular}

${ }^{\mathrm{a}}$ One hectolitre is equivalent to $100 \mathrm{~L}$.

Source: Wester (1920, p. 10).

overall land area of the Philippines or 29.6 million ha was categorized as idle land for future cash crop production (Hill, 1925, p. 20).

As a whole, Philippine rice supply increased because of the appropriation of unpaid work from the draft animals, which occurred through three particular pathways: state power in buying out the friar lands, land arrangements in coercing the agrarian classes of labour, and importing thousands of draft animals for agricultural work. As appropriation persisted, the colonial regime relegated the reproduction cost of draft animals to the agrarian worker. These actions led to a higher market cost and lengthier training time of draft, which signalled downward mobility for the agrarian classes. In the next section, I will examine how this rice surplus became the basis for the emergence of Philippine coconut and sugar sectors in the global market.

\section{5 | FROM COCONUT GEOGRAPHIES TO COCONUT COMMODITIES (1921-1941)}

Coconut's demand only dramatically increased at the end of the 19th century. Following the invention of highdemand household goods, such as the modern soap, coconut oil, and biscuits (Barrett, 1913a, p. 28; Woodroof, 1979, pp. 5-6), the British and the Dutch begun coconut plantations and production in Ceylon and the East Indies in the late 19th century. At that time, hemp, tobacco, and sugar were the Philippines' main exports, whereas coconut 
only occupied a very minor percentage. As this timeline suggests, during the initial stages of U.S. colonization and largely due to the rice deficit, the Philippines could not produce huge quantities of coconuts (Barrett, 1913b, p. 243). After resolving the particular deficit at the first half of U.S. colonization, the Philippine Islands stood to become the largest coconut producer and exporter in the world. ${ }^{18}$

Compared with sugar, which require huge capital investments to compete in the export markets, coconuts only need minimal expenditure to begin production. N. H. Duckworth, an American investor in Philippine agriculture, said that "[coconuts] groves containing from ten to fifty thousand bearing trees are not so uncommon" (Elliot, 1916, p. 359). As Tables 5 and 6 show, it took 5 years for new seeds to sprout and grow. Eventually, American capital, strong winds, and stony ridges transformed the provinces of Tayabas, Laguna, and Zambales into the island's largest coconut producing areas (Elliot, 1916, p. 361). Between 1899 and 1909, there were less than 100,000 acres of coconut land, but by 1910, coconut production had already taken over 405,000 acres. By 1920 , the coconut industry had a firm place in the global market.

As the planting of coconut trees continued, the colonial regime invested more capital to construct modern irrigation, roads, and transportation (Robb, 1925b, p. 3). At the same time, the regime also invested capital to develop labour-saving devices that could limit manual labour in coconut production. In the 19th century, coconuts were previously husked through the mattock or heavy hoe and then dried under the sun, or through the plowpoint, a device "fixed on a three-legged stand," that extracted meat from the coconut shell (The American Chamber of Commerce, 1926, p. 32). By the 1920s, the Tapahan, a new device from Ceylon, enjoyed great popularity across the Philippine plantations. Unlike the plowpoint that was limited to specific areas of the plantation, the Tampahan could be easily moved from one area to another in order to efficiently shred coconut meat from the raw coconut. Afterwards, farmers removed the copra while "oil extracted [is] in the grove" and then crushed and cooked twice (The American Chamber of Commerce, 1926, p. 32).

Furthermore, large-scale plantations adapted mechanized dryers with "update-to-date methods" (The American Chamber of Commerce, 1932a, p. 6), whereas small landowners used tiny dryers that "have been devised" to replace the "smudge-drying process which discolors the copra" (The American Chamber of Commerce, 1932a, p. 6). By 1923, these machines reduced drying time from $24 \mathrm{hr}$ to approximately $10 \mathrm{hr}$, sufficient to "take care of $200 \mathrm{ha}$ [hectares], 20,000 trees, 100 trees to the hectare, with an average yield of 60 nuts per tree [shid] per annum" (The American Chamber of Commerce, 1923, p. 6). Moreover, instead of the 10 to 20 men that it usually took to manage, the mechanized dryers required only "two men and a boy working in two shifts each 24 hours" to operate (The American Chamber of Commerce, 1923, p. 6). Using these new tools, workers "can cut down from 1,000 to 2,000 nuts a day" and can "husk 2000 or rasp the meat from about 1,000 nuts per day" (Byars, 1908, p. 520).

The changes from labour-intensive agriculture to machine-reliant production intensified the appropriation of unpaid work. Although new coconut labour-saving devices displaced workers from some aspects of production, the plantations simply used the excess pool of workers to extract more produce from the coconuts: copra, coconut oil, and coconut shells. Using carabaos and boats, some of these workers were transferred to new farms or the frontier areas of the plantation to expand cultivation. ${ }^{19}$

Because the coconut sector needed far less land than that for rice production, it was a more profitable sector. In 1937, 800,000 agrarian labour were working for and fully depended on the coconut industry (Waring \& Dorfman, 1937, p. 35). The agrarian labour's families also worked for the coconut sector. During some seasons, approximately 4 million people or over $30 \%$ of the colony's population joined the operation, working intermittently and transiently in the different phases of production, mostly completing labour-intensive work using the carabaos, or assisting "full-time" agrarian labour in some aspect of the cultivation (Waring \& Dorfman, 1937, p. 30).

\footnotetext{
${ }^{18}$ Sunlight and the monsoon winds made coconut crops fertile on the typhoon-laden coasts of the Pacific and the Indian Ocean (Mandal, 2000).

${ }^{19} \mathrm{~A}$ different aspect of unpaid work is the agrarian workers' boat faring skills, which transported goods from the plantation to the ports more cheaply (Elser, 1925). Multiple rivers in the Philippines enabled the steady and ease transportation of the harvested raw coconuts, as well for the "finished" copra, coconut oil, and desiccated coconuts (Elser, 1925).
} 
TABLE 5 Planted coconut trees in Laguna

\begin{tabular}{llcc} 
Years & Planted coconut trees & Bearing coconut trees & Nuts gathered \\
\hline 1910 & $3,537,920$ & $\mathrm{n} / \mathrm{a}$ & $140,383,000$ \\
1915 & $4,579,560$ & $\mathrm{n} / \mathrm{a}$ & $110,067,000$ \\
1920 & $8,605,620$ & $5,806,850$ & $255,395,000$ \\
1924 & $9,049,230$ & $6,374,650$ & $294,081,000$ \\
\hline
\end{tabular}

Note. $\mathrm{n} / \mathrm{a}=$ not available.

Source: Robb (1925a, p. 8).

TABLE 6 Planted coconut trees in Tayabas

\begin{tabular}{lccc} 
Years & Planted coconut trees & Bearing coconut trees & Nuts gathered \\
\hline 1910 & $5,551,900$ & $\mathrm{n} / \mathrm{a}$ & $162,560,000$ \\
1915 & $7,501,790$ & $\mathrm{n} / \mathrm{a}$ & $147,041,000$ \\
1920 & $17,986,980$ & $7,620,270$ & $331,197,000$ \\
1924 & $18,666,260$ & $9,829,010$ & $309,287,000$ \\
\hline
\end{tabular}

Note. $\mathrm{n} / \mathrm{a}=$ not available.

Source: Robb (1925a, p. 8).

Although all of the land arrangements were harmful to the tenants, some terms were worse than others. The share tenancy system, the most common model and one that most closely resembled other landowner-labour relations in the 19th century, only awarded the tenants $85 \%$ of the proceeds after developing the plots and working on the crops (Waring \& Dorfman, 1937, p. 30). The landlord only pay the taxes and negotiate the terms of sale in exchange for the remaining 15\% proceeds (Waring \& Dorfman, 1937, p. 30). In some plantations, agrarian workers were paid a daily wage ranging from US $\$ 0.13$ to US $\$ 0.25$, or obligated by a system of customary relations to work for free during particular days (Robb, 1925b). Other arrangements revealed the entanglements between the newly modernized capitalized coconut industry and that of other agricultural products (Mcllvaine, 1923, p. 12), using rice supplies, hemp, and abaca to pay agrarian workers (Waring \& Dorfman, 1937, p. 31). As payment for work, these agricultural produce acted as an indirect subsidy to keep the wage bill of U.S. capitalists and Philippine elites low.

Coconut also has a specific form of appropriation that emerged from the crop's commodity features. Specifically, the diversity of coconut products made it flexible for different means of payments, labour control, and product output. Because coconuts were horticultural, the ploughing and husking of the crop simultaneously occurred with the cultivation of other crops (Robb, 1925b, p. 3). When the prices of other agricultural commodities increased in the world market, landlords would use the much lower-priced coconuts to pay the Philippine agrarian workers: "coconut meat substituted for rice"; juice or "tuba" added to water; coconut leaves covered houses; coconut shells became plates; coconut oil became shampoo; and the "copra fed the carabao" (The American Chamber of Commerce, 1921, p. 9). When there was a need to use rice for domestic consumption or save revenues to upgrade agricultural infrastructure in the plantation, the colonial regime relied on the coconuts as a means of payment to the workers. Furthermore, despite the fact that small landowners planted coconuts in their own plots, they lacked access to the global market and thus could only sell their products to the landlords by default. The landlords were able to use these products as payment to their workers and tenants.

The fortunes of U.S. capitalists, Philippine elites, and multiple cities were built on the coconut. Before the 1920, raw copras contributed to the bulk of the Philippine exports, which lost to the superiority of the sun-dried Ceylon and Javanese copra (Robb, 1925a, p. 18). After 1920, the introduction of drying and processing technologies, the products of Philippine coconuts further diversified by the mid-1920s (Waring \& Dorfman, 1937, p. 32): 93\% were converted into copra and coconut oil and $6 \%$ into desecrated coconut, whereas $1 \%$ was kept for local consumption. 
In 1922, 450,000 ha used planted for coconuts, which produced 5.8 million piculs of copra worth US $\$ 22$ million in that year alone (The American Chamber of Commerce, 1923, p. 6). By the 1930s, there were 13 major coconut-growing provinces producing an average of half a million metric tons of coconuts per year (Fehr \& Company, 1937, p. 6). The island of Cebu alone produced $60 \%$ of the copra, and the rest were shipped from the ports from Legaspi, Bulacan, Zamboanga, Cagayan, Manila, Iloilo, Tacloban, Masbate, Davao, and others (Fehr \& Company, 1937, pp. 6-7).

The appropriation of unpaid work enabled the Philippines to become the fastest growing coconut producing country in the world. In 1923, the Philippines provided 33\% of world's copra and coconut oil, and by 1934 , the Philippines supplied $38 \%$ of the world's production of coconut products (Waring \& Dorfman, 1937, pp. 30-31). Alongside the global market's growing demand for biscuits, oleomargarine, soap, cleaning materials, and others, the demand for coconut oil also increased. However, because of the slump in the demand for all commodities during the great depression in the 1930s, producing higher volumes of coconut products did not mean higher profit for the U.S. colonial regime. To illustrate, the amount of coconut oil exports increased from 129,291 tons in 1926 to 182,095 tons in 1936 , but total revenue decreased from US\$11.1 million to US\$3 million (Waring \& Dorfman, 1937, p. 33). As depicted in Tables 7 and 8, the Philippines captured second place in world copra exports and successfully championed the coconut oil market by 1934. Competing coconut exports from various colonial regimes eventually glutted the market, leading to the fall in copra prices from US\$11.30 per ton in 1926 to US $\$ 6.90$ per ton in $1936 .^{20}$

As illustrated in Table 9, Philippine exports also heavily relied on and subsidized the U.S. consumer market (Arnold, 1921, p. 23; White, 1921, p. 28). As early as the 1920s, as Mcllvaine (1923) observed, "copra is entering on a new era... manufacture of soap is ever increasing its demands for copra... there is no tropical crop that can compare with coconut planting today" (p. 12). In 1936, approximately 60\% of U.S. coconut oil imports made 3 billion Ibs of soap annually. The abundance of cheap coconut oil imports made it possible for U.S. companies to export billions of pounds of domestic low-grade refuse oils and fats, which were previously used to make soap, to Europe. An American businessman trying to reach a compromise with protectionist groups in the 1920s addressed the specifics of coconut's role in the domestic market, noting that "exclude coconut oil and, consequently, make much inferior soap from domestic products exclusively, or impose a heavy duty on it, and thus correspondingly increase the price" (The American Chamber of Commerce, 1932a, p. 22). Not only did the coconut's byproducts figure into a less costly way to make soap, the coconut oil served an additional purpose of producing oleomargarine. Using only $0.53 \mathrm{lb}$ of coconut oil, U.S. capitalists can produce a single item of oleomargarine, an item that later became known as the butter of the working class. So popularized by its low price, by 1935 , oleomargarine accounted for approximately $16.9 \%$ of butter overall, providing a cheaper alternative to the more expensive Danish or New York butter.

Cheaper than regular oil by $25 \%$ in the early 20 th century, coconut oil also became a more attractive substitute (The American Chamber of Commerce, 1932a, p. 18). While it could not effectively fry all kinds of meat, its composition allowed for cooking and preparing a variety of items, including salad dressing, vegetable, and soft meat. As compared with more specialized items such as cottonseed, another alternative product for vegetable and salad oil, the versatile coconut oil performs similar functions but cost approximately US $\$ 0.06$ cents less per pound. Because coconut oil was more attractive to capitalists, this enabled the U.S. regime to export 30-40\% of its own domestic lard and fat to Europe for cooking.

Although coconut oil was produced primarily with the American consumer household in mind, the U.S. military imported Philippine copras for weapons development. ${ }^{21}$ Specifically, as the product of the experiments, "the coconut has been applied to the recovery of solvents used in manufacture of artificial leather such as used in automobile finishing, furniture finishing, and other uses of a highly specialized nature" (Merritt, 1927, p. 22).

\footnotetext{
${ }^{20}$ The market for copra and coconut oil initially decreased in 1929-1930s but recovered soon after the New Deal, increasing the demand for both crops. Although sugar earned more profit, coconuts had a higher demand and exported more.

${ }^{21}$ See Merritt (1927).
} 
TABLE 7 Total copra exports to the world market (in metric tons), 1925-1934 ${ }^{a}$

\begin{tabular}{|c|c|c|c|c|c|}
\hline Copra exporter & 1925 & 1930 & 1934 & $\begin{array}{l}\text { Yearly average from } \\
1925 \text { to } 1934\end{array}$ & $\begin{array}{l}\text { Share of } \\
\text { total in \% }\end{array}$ \\
\hline Philippines & 146,200 & 166,780 & 346,271 & 197,727 & 22.6 \\
\hline Netherlands Indies & 206,609 & 375,374 & 407,040 & 368,395 & 41.8 \\
\hline Malaya & 99,156 & 116,460 & 86,928 & 110,484 & 12.6 \\
\hline Ceylon & 112,546 & 88,800 & 105,681 & 92,205 & 10.5 \\
\hline South Sea Islands & 100,000 & 100,000 & 159,000 & 110,000 & 12.5 \\
\hline Malabar Coast & $\mathrm{n} / \mathrm{a}$ & $\mathrm{n} / \mathrm{a}$ & $\mathrm{n} / \mathrm{a}$ & 679 & .1 \\
\hline Total & 664,511 & 843,020 & $1,095,929$ & 880,491 & 100 \\
\hline
\end{tabular}

Note. $\mathrm{n} / \mathrm{a}=$ not available.

aTables 7 and 8 pertain to the overall weight of copra exports and coconut oil exports to the world market. In the metric system, a single ton is $2,240 \mathrm{lbs} / \mathrm{ton}$. It would be difficult to find the weight of the copra because it varies according to the packaging. However, an example of a coconut should suffice. If a single coconut is $3.2 \mathrm{lbs}$, then by dividing $2,240 \mathrm{lbs}$ by the weight of the coconut, there should be 622 coconuts per metric ton. In 1925 alone, the Philippines exported 146,200 in that year or 400 tons of copra per day, which translates to 248,800 coconuts a day.

Source: Fehr and Company (1937).

TABLE 8 Total coconut oil exports to the world market (in metric tons), 1925-1934

\begin{tabular}{|c|c|c|c|c|c|}
\hline Coconut oil exporter & 1925 & 1930 & 1934 & $\begin{array}{l}\text { Yearly average from } \\
1925 \text { to } 1934\end{array}$ & $\begin{array}{l}\text { Share of } \\
\text { total in \% }\end{array}$ \\
\hline Philippines & 193,137 & 289,613 & 363,151 & 270,253 & 34.4 \\
\hline Netherlands Indies & 139,464 & 251,141 & 258,967 & 246,657 & 31.4 \\
\hline Malaya & 70,094 & 85,903 & 80,562 & 81,748 & 10.4 \\
\hline Ceylon & 98,485 & 94,602 & 136,417 & 100,516 & 12.8 \\
\hline South Sea Islands & 63,000 & 63,000 & 94,500 & 69,300 & 8.8 \\
\hline Cochin China & 15,397 & 20,869 & 13,404 & 16,057 & 2.1 \\
\hline Total & 579,577 & 805,128 & 974,001 & 784,959 & 100 \\
\hline
\end{tabular}

Source: Fehr and Company (1937).

TABLE 9 Value of all principal coconut products to the United States and the world

\begin{tabular}{|c|c|c|c|c|}
\hline & \multicolumn{2}{|c|}{ Value of principal coconut products } & \multicolumn{2}{|c|}{ Ratio of value of exports of principal coconut products } \\
\hline & $\begin{array}{l}\text { To all countries } \\
\text { in US\$ }\end{array}$ & $\begin{array}{l}\text { To the United } \\
\text { States in US\$ }\end{array}$ & $\begin{array}{l}\text { Ratio of coconut exports } \\
\text { to the overall amount } \\
\text { of Philippine exports in \% }\end{array}$ & $\begin{array}{l}\text { Ratio of coconut exports } \\
\text { to the United States to the } \\
\text { overall coconut exports to } \\
\text { other countries in \% }\end{array}$ \\
\hline 1926 & $45,425,830$ & $38,833,102$ & 33.2 & 38.8 \\
\hline 1930 & $37,443,888$ & $32,902,818$ & 28.1 & 31.2 \\
\hline 1935 & $28,843,650$ & $25,670,716$ & 30.6 & 34.3 \\
\hline
\end{tabular}

Source: Waring and Dorfman (1937, p. 36).

As Table 10 shows, American capital effectively transformed the Philippines into one of the world's coconut exporters, supplying cheap coconut inputs to the American factories to sell products to the U.S. domestic market. In 1899, there were only about a thousand acres of coconut lands, but by 1934, approximately 1.4 million acres were used for coconut production. The American state and business groups heavily invested in Philippine coconut lands. From 1901 to 1934 , an approximate amount of US\$194 million was used on lands and US\$905,000 on mechanizing 
TABLE 10 Philippine coconut exports, 1899-1934 (commodities in metric tons)

\begin{tabular}{lcccccc} 
Year & Acres used & Copra & Coconut oil & Copra cake & Desiccated & $\begin{array}{c}\text { Total exports } \\
\text { per metric ton }\end{array}$ \\
\hline 1899 & $\mathrm{n} / \mathrm{a}$ & 15,000 & $\mathrm{n} / \mathrm{a}$ & $\mathrm{n} / \mathrm{a}$ & $\mathrm{n} / \mathrm{a}$ & 15,000 \\
\hline 1905 & $\mathrm{n} / \mathrm{a}$ & 55,000 & $\mathrm{n} / \mathrm{a}$ & $\mathrm{n} / \mathrm{a}$ & $\mathrm{n} / \mathrm{a}$ & 55,000 \\
\hline 1910 & 405,000 & 119,000 & $\mathrm{n} / \mathrm{a}$ & $\mathrm{n} / \mathrm{a}$ & $\mathrm{n} / \mathrm{a}$ & 107,000 \\
\hline 1915 & 669,000 & 137,000 & 13,000 & $\mathrm{n} / \mathrm{a}$ & $\mathrm{n} / \mathrm{a}$ & 167,000 \\
\hline 1920 & 981,000 & 25,000 & 76,000 & 35,000 & $\mathrm{n} / \mathrm{a}$ & 143,000 \\
\hline 1925 & $1,177,000$ & 144,000 & 102,000 & 55,000 & 8,000 & 317,000 \\
\hline 1930 & $1,361,000$ & 172,000 & 145,000 & 89,000 & 22,000 & 436,000 \\
\hline 1934 & $1,484,000$ & 346,000 & 145,000 & 102,000 & 34,000 & 643,000 \\
\hline
\end{tabular}

Note. $\mathrm{n} / \mathrm{a}=$ not available.

Source: Waring and Dorfman (1937, p. 29).

coconut production. In relative terms, the amount of capital was massive in contrast to investments in other parts of the world in the early 20th century: US $\$ 13.9$ million in U.S. territories, US $\$ 4.7$ million in the Spanish colonies, US $\$ 3.4$ million in the British Commonwealth, and US\$3.5 million for the rest of the world (Waring \& Dorfman, 1937, p. 32).

In sum, the capitalization of the coconut sector-planting coconut lands, constructing infrastructure, and mechanizing parts of production-occurred alongside the three particular pathways of appropriation: (a) the colonial regime's capacity to open up the U.S. market and legal protection given to coconut plantations; (b) the land arrangements of using agrarian workers, their families, and draft animals in different phases of coconut production; and (c) the coconut seed's self-expanding feature and the crop's fungibility as means of payment to the workers. In 1939 alone, American and Philippine coconut exporters earned US $\$ 26$ million by relying on 4 million agrarian workers in the Philippine coconut sector (The American Chamber of Commerce, 1939). Although the coconut was profitable, it was not the only lucrative export of the American regime. The next section discusses how the appropriation of unpaid work made sugar a major Philippine export.

\section{6 | FROM SWEET ISLANDS TO SWEET PRODUCTS (1921-1941)}

Although sugar was integral in previous waves of capitalism from the 16th century to the 18th century (e.g., Moore, 2000, 2009), the crop was of marginal significance in Spanish Philippines until the latter parts of the 19th century (e.g., Hines, 1915; Legarda, 1999). Despite greater attention given by the Spanish government during the last few decades of its rule, Philippine plantations were producing low-grade, muscovado sugar for global export (Fairchild, 1921, p. 28). As the Spanish regime never bothered to build centrifugal mills, expand irrigation, and increase fertilization, the sugar sector occupied a small market niche of providing low-grade sugar for the global economy (Waring \& Dorfman, 1937, p. 23). Although Foreman (1905) notes that in the "absence of proper banking facilities, certain commercial firms financed the business and production of sugar" (p. 350), the Philippine sugar sector was relatively uncapitalized and unmechanized than that of other sugar exporting colonies. This was the state of the sugar sector at the start of the American colonial rule in 1901.

Although coconut production concentrated in Luzon and Mindanao, sugar was largely located in the Visayas region. Negros and Panay, islands in the Visayas region, had the proper location, size, soil, and wind patterns for abundant production (Waring \& Dorfman, 1937, pp. 23-34). Similar to the Caribbean, Cuba, Hawaii, and other sugar centres of the world, the fertile lands of the islands provided the prime conditions for sugar production (Smith, 1925a, pp. 26-27). Because of their proximity to surrounding bodies of water, island geographies fit the unique terms necessary for sugar production (Smith, 1925b, p. 8). 
Although the colonial regime knew that muscovado sugar was uncompetitive in the global market at first glance, they saw the opportunity afforded by the growing demand for sugar and the availability of more sophisticated methods (Hines, 1915, p. 7). As a result, the colonial regime developed the sector though banking credits, mechanization, and experimentation on new crop varieties. With investments worth US\$20 million (Mcllvaine, 1923, p. 12), centrifugal sugar mills replaced and upgraded the crude sugar facilities. In some other areas, provincial and local landowners amortized their land in exchange for loans from Hawaiian and New York sugar companies (The Philippine Agricultural Review, 1919, p. 45). One by one, centrifugal sugar mills slowly took over many of the sugar production plantations of the colony. By 1922, 31 centrifugal sugar mills and two sugar refineries made up the bulk of sugar production (The American Chamber of Commerce, 1924, pp. 18-19).

Between 1901 and 1910, the colonial regime transformed the sugar mills from crude to centrifugal facilities (Hines, 1915), transforming the sugar output qualitatively. However, replacing and upgrading sugar production infrastructure did not increase sugar quantitatively. Arnold Warren, a well-known accountant and sugar chemist in 1920s, reported that "thirty years ending with 1922 the total output of Philippine sugar had remained practically stationary" (Warren, 1924, p. 9). In fact, it would be a mistake to view the transition from crude to centrifugal sugar as a complete transformation from labour-intensive to capital-intensive production. Even though factories needed less workers to produce the same amount of sugar, the colonial regime still required a huge supply of workers for harvesting, seeding, transporting, planting, cutting, and stripping. As a result, the colonial regime resorted to two measures to appropriate unpaid work.

In the first measure, the colonial regime "increase[d] the area planted to cane" through the expansion of the sugar lands (Warren, 1924, p. 9). For decades, these lands belonged to small landowners and farmers who relied upon simpler methods of muscovado sugar production. However, to expand the production of centrifugal sugar output, the U.S. period oversaw and facilitated the ownership of land, milling, and transportation of few hacienda owners over to the coastlines (Warner, 1939, p. 53). In other words, the colonial regime took lands from small farmers and consolidated them into the hands of very few sugar elites (Cooper, 1928, pp. 22). Slowly and surely, sugar production became a heavily controlled and vertically linked enterprise due to the newly captured sugar plantations in Batangas and Laguna. The multiple phases of production-planting, cultivating, milling, refining, and transporting-became interlinked, and the small landowners were accordingly absorbed into bigger production centres. Eventually, the colonial regime expanded the sugar lands into newly sequestered lands and untouched frontiers in the coastal areas of Luzon. Before 1920, a total of 487,000 acres were used for sugar cultivation, but by 1934, the lands grew to 755,000 acres (The American Chamber of Commerce, 1922, p. 23; Gamboa, 1937, p. 13).

The second measure was to increase the quantity of sugar produced per unit area (Warren, 1924). For this to occur, the colonial regime used more agrarian workers in every possible step of production across all the sugar plantations. An American commentator said that harvesting was still "all done by hand," usually by "women and children" who received US $\$ 0.05$ to US $\$ 0.10$ for a working day of 10-12 hr (Hines, 1915, p. 12). Afterwards, the same workers were used to distribute the fertilizers across the acres of land (Hines, 1915, pp. 15-16) and plant experimental refined sugar canes on specific soils. As seen in Table 11, refined sugar expanded from 162,000 in 1923 to 483,000 metric tons in 1924 (Insigne, 1926, p. 27), which finally made the Philippines competitive in the U.S. market. On large-scale plantations, tractors and draft animals were used side-by-side and interchangeably for ploughing, disking, and husking crops (Insigne, 1926, p. 27). At the same time, agrarian classes of labour and draft animals were also used to expand the sugar frontiers for future production (Cooper, 1928, p. 21). These measures resulted in an increase of sugar yields. For example, sugar tons in 1925 were higher by 10,000 than the previous year (Gowen, 1937, p. 20).

State power, land arrangements, and the sugar's specific characteristics shaped the particular forms of appropriation in sugar production. Planting occurred from December until April: harvesting crops, stripping stems, cutting down stalks, and transporting raw sugar to the mills. ${ }^{22}$ Workers burned the stalks in order to easily harvest the crops

\footnotetext{
${ }^{22}$ Due to the specific historical geography of winds and rain patterns of South-east Asia and the Pacific, the planting did occur from December to April.
} 
TABLE 11 Quantity of Philippine sugar exports from 1920 to 1934

\begin{tabular}{llcccc} 
Year & Area & $\begin{array}{l}\text { Increase in area } \\
\text { compared with } \\
1920 \text { in } \%\end{array}$ & $\begin{array}{l}\text { Increase in total } \\
\text { productioncompared } \\
\text { with } 1920\end{array}$ & Yield per acre & $\begin{array}{l}\text { Total yield } \\
\text { per year }\end{array}$ \\
\hline 1920 & 487,775 & $\mathrm{n} / \mathrm{a}$ & $\mathrm{n} / \mathrm{a}$ & 0.957 & 466,912 \\
1930 & 640,073 & 31.2 & 110.7 & 1.537 & 983,767 \\
\hline 1934 & 775,861 & 55.0 & 253.9 & 2.816 & $1,652,593$ \\
\hline
\end{tabular}

Note. $\mathrm{n} / \mathrm{a}=$ not available.

Source: Waring and Dorfman (1937, p. 23).

and, afterwards, started "plowing and cross plowing [the soil] until it is well broken up" (Hines, 1915, p. 6). Thus, for both sugar and coconuts, stable rice supplies paid for portions of the total wage. But unlike coconuts, sugar could not be used as a means of payment for the workers due to its limited usage in household consumption, resulting in higher wages for workers in the sugar plantations (The American Chamber of Commerce, 1937). Wages varied across sugar plantations, but the most common arrangement of landlord-tenant relations paid workers US $\$ 0.15$ to US $\$ 0.25$ a day (Waring \& Dorfman, 1937, p. 24). Apart from the workers, draft animals pulled the wooden harrows on the seedbed and were then set to graze the land for the rest of the day. Sugar crops were brought to small mills and then mixed with lime and water inside a boiling kettle until the concentration is made (Hines, 1915).

Overall, the expansion of unpaid work exponentially increased the sugar output from the 1920s to 1930s. In 1921, a total of 319,000 tons worth US\$25 million were exported, but by 1934 (Cooper, 1928, p. 22; Waring \& Dorfman, 1937, p. 25), total sugar exports reached 1.2 million tons worth US\$65 million, and the average yield of sugar per acre rose from 0.957 to 2.186 per ton (The American Chamber of Commerce, 1937, p. 38). Illustrated in Table 12, Philippine sugar experienced an annual average increase of 223\% from 1925 to 1935 and surpassed the Dutch share of Javan sugar in the world market (Butler, 1925, p. 2; Waring \& Dorfman, 1937, pp. 25-26).

By 1934, 15\% or 2 million of the Philippine population was employed in the sugar industry-90\% of Negros Occidental and Pampanga, 60\% of Tarlac, 50\% of lloilo and Batangas, and 10\% in Cebu (Gamboa, 1937, p. 13; Waring \& Dorfman, 1937, pp. 24-25). The class composition of the sugar industry's workers identifies the colonial regime's combination of exploitation and appropriation-15,000 were huge and small planters, 175,000 tenants in the fields, and 25,000 workers in the factories (Waring \& Dorfman, 1937, p. 25). Although factory workers received a daily wage of US $\$ 0.50$ to US $\$ 0.75$ (Waring \& Dorfman, 1937, p. 24), plantation tenants were only paid US $\$ 0.15$ to US $\$ 0.25$ (The American Chamber of Commerce, 1947; Lava, 1946, p. 8). Although the payment differences were stark, these numbers do not reflect the number of draft animals, women, and children who were involved in the production of sugar across the different phases of production (Youngberg, 1929, p. 125). Along with the other colonies of Hawaii and Puerto Rico, the Philippines became a key source of sugar for the American economy (see Table 13).

Despite the higher volume of coconut exports, sugar was priced higher in the world market. Like the coconut, sugar also played key role in American consumer market. Sugar often comprised many domestic household goods: alcohol, chocolate bars, meat, tea, coffee, and many others (Waring \& Dorfman, 1937, p. 26). For imperial politics, the Philippine sugar exports allowed the U.S. Government to resist sugar tariff wars with the Dutch East Indies,

TABLE 12 Share of Philippine sugar exports from 1920 to 1934 (in short tons) $^{\text {a }}$

\begin{tabular}{rlllllllrr} 
Year & World & $\begin{array}{l}\text { Continental United } \\
\text { States }\end{array}$ & Philippines & \multicolumn{1}{l}{$\begin{array}{l}\text { Other U.S. } \\
\text { colonies }\end{array}$} & Cuba & \multicolumn{1}{l}{ Java } & \multicolumn{1}{l}{ India } & \multicolumn{1}{l}{$\begin{array}{l}\text { Japanese } \\
\text { empire }\end{array}$} \\
\hline 1925 & $27,246,000$ & $1,040,000$ & 489,000 & $1,403,000$ & $5,471,000$ & $2,230,000$ & $3,334,000$ & 691,000 \\
1930 & $31,899,000$ & $1,415,000$ & 876,000 & $1,786,000$ & $3,497,000$ & $3,315,000$ & $3,604,000$ & $1,040,000$ \\
1935 & $31,864,000$ & $1,561,000$ & 995,000 & 218,000 & $2,899,000$ & 635,000 & $6,834,000$ & $1,223,000$ \\
\hline
\end{tabular}

${ }^{\mathrm{a}}$ One short ton is equivalent to $2,000 \mathrm{lbs}$.

Source: Willet and Gray (1935). 
TABLE 13 Quantities and values of raw sugar exported from the Philippines to all countries and the United States, 1921-1934

\begin{tabular}{|ccllcl} 
Year & $\begin{array}{l}\text { Quantity of } \\
\text { total exports }\end{array}$ & $\begin{array}{l}\text { Value of total } \\
\text { exports in US\$ }\end{array}$ & $\begin{array}{l}\text { Percentage of sugar to } \\
\text { Philippine exports }\end{array}$ & $\begin{array}{l}\text { Quantity of total exports } \\
\text { to the United States }\end{array}$ & $\begin{array}{l}\text { Value of total exports to } \\
\text { the United States in US\$ }\end{array}$ \\
\hline 1921 & 319,532 & $12,759,363.5$ & 29.0 & 165,874 & $8,438,339$ \\
\hline 1925 & 603,099 & $22,934,043$ & 30.6 & 511,804 & $20,709,898.5$ \\
\hline 1930 & 822,201 & $26,122,074$ & 39.2 & 814,736 & $16,045,945$ \\
\hline 1934 & $1,275,313$ & $32,727,290$ & 59.3 & $1,275,250$ & $31,726,810.5$ \\
\hline
\end{tabular}

Source: Waring and Dorfman (1937, p. 25).

the British Malaya, and even the Japanese Empire. The price of sugar remained stable during this time despite the rising demand by the American working class and the changes induced by the New Deal (Gowen, 1937, p. 20; The American Chamber of Commerce, 1939, p. 34).

Like the coconut industry, the Philippine sugar sector received a significant portion of global capital. Specifically, from the 1920 s to the 1941 , investments reached a total of US $\$ 200$ million in the Philippines but only US $\$ 25$ million in the rest of the world (Waring \& Dorfman, 1937, p. 28). Sugar investment increased throughout the decades; from 1920 s to 1941 , sugar production plantations received US $\$ 84$ million to upgrade production technologies. Supporting infrastructures and nearby roads received US $\$ 181$ million to expand the sugar frontier, improve transportation, and maintain the soil (Waring \& Dorfman, 1937, p. 28). Comparatively, the US, the British, Spanish, and other territories received little sugar investment during the early 20th century.

With 45 sugar processing plants spread across the colony, a milling capacity of 12 million tons of sugar cane every 150 days, and 2 million workers, Philippine sugar output peaked at 71,000 tons per day in 1934 (Waring \& Dorfman, 1937, p. 24). ${ }^{23}$ The capitalization of sugar-shift from muscovado to refined, the construction of infrastructure, and using factory workers in parts of production-occurred alongside the three particular pathways: (a) the colonial regime's power to coerce small landowners in the coast, those who maintained their autonomy from the friar lands and other land arrangements-into surrendering their land; (b) land arrangements that made agrarian workers and draft animals apply more labour in particular types of land; and (c) sugars need to be planted in the coastal areas and the use of fertilizers to expand the crop's output.

\section{I CONCLUSION}

The article has three central contributions. First, by demonstrating that unpaid work is central and indispensable to food production, the article changes how we think about food regimes. The analysis of production relations demonstrates how different states, land arrangements, and commodity-specific features jointly construct food regimes. The empirical analysis of unpaid work and production relations through these different "pathways" gives a more complete picture of food regimes. Moore's works on sugar and the broader literature on neoliberal world agriculture have sought to engage the problem of production in conceptual frames similar to food regimes. Taking these issues a step further, the article breaks new ground by showing that draft animals are co-constitutive in the making of food regimes. Although conventional works in critical political economy treated draft animals as commodities, objects, or simply fixed or circulating capital, other scholarships in political ecology and anthropology analysed draft outside the crucial domain of political economy. Works in the food regimes have either followed these assumptions or ignored draft animals as a whole. In contrast, the paper demonstrates that draft animal not only played a role but was crucial in providing vast amounts of unpaid work to the production of Philippine rice, coconut, sugar for the

\footnotetext{
${ }^{23}$ The U.S. colonial regime used the metric system. A single ton is worth $2,240 \mathrm{lbs}$ of sugar.
} 
American working class, and their commodified labour power. This calls for more research on the role that draft animals play in the global economy.

Second, other works demonstrated the significance of the working class and their labour power to American capitalism and hegemony, but my work adds geographic, conceptual, and empirical layers to the centrality of food regimes to the U.S. economy. Specifically, my work furthers the empirical literature on U.S. colonization of the Philippines. Although accounts have focused on the political, economic, and cultural impacts of imperialism, the colonization literature has generally overlooked the environmental and political economic processes that simultaneously unfolded. Even though these accounts mention the environment, they have often underexamined the political economic dimensions of these processes, only analysing the impact of American rule on the Philippine environments. In contrast, my work shows that the food regime and the American colonial regime organized the environments of the Philippines to appropriate unpaid work for the commodified labour power of Philippine and American workers.

And lastly, for the study of world-ecology, I suggest that we can move back and forth between a general and historically specific forms of appropriation. Although the article's empirical narrative shows that pathways of appropriation occur similarly in rice, coconut, and sugar, it also highlights the contextual and contingent forms of appropriation across peoples, geographies, and temporalities. Within the contours of world history, the Philippine contexts reveal the general and specific forms of appropriation, making us more cognizant of appropriation through colonial state power, land arrangements, and commodity-specific features. From the specific forms, appropriation becomes general once again as it transfers unpaid work from the agrarian classes of labour to agriculture commodities, subsidizing the food regime's operational costs and contributing to the accumulation of capital. Although exploitation demonstrates a general logic to expand commodity relations, appropriation shows flexibility, changes, and emergence. Although I used a historical approach to analyse paid and unpaid work, future researchers can also use ethnographic, statistical, and other methods to examine the general and historically specific forms of appropriation in capitalism.

\section{ORCID}

Alvin A. Camba (D) http://orcid.org/0000-0003-4082-8411

\section{REFERENCES}

Araghi, F. (2003). Food regimes and the production of value: Some methodological issues. The Journal of Peasant Studies, $30(2), 41-70$.

Araghi, F. (2009). Accumulation by displacement: Global enclosures, food crisis, and the ecological contradictions of capitalism. Review: A Journal of the Fernand Braudel Center, 113-146.

Arnold, G. C. (1921). "Copra and its products". The American Chamber of Commerce, January, 23.

Barrett, O. W. (1913a). The Philippine coconut industry. Philippine Agricultural Review. Government of the Philippine Islands. Bulletin, 25, 28-40.

Barrett, O. W. (1913b). "Current notes". The Philippine Agricultural Review. Vol. VI, No. 5: 243-256.

Bernstein, H. (2010). Class dynamics of agrarian change (Vol. 1). West Hartford: Kumarian Press.

Bonnano, A., Busch, L., Friedland, B., Gouveia, L., \& Mingione, E. (1994). From Columbus to ConAgra: The globalisation of agriculture and food. KS: University of Kansas Press.

Borras, S., McMichael, P., \& Scoones, I. (2010). The politics of biofuels, land and agrarian change: Editors' introduction. The Journal of Peasant Studies, 37(4), 575-592.

Buencamino, V. (1926). "Our meat supply". The Philippine Agricultural Review. Vol. XV, No. 4: 241-245.

Burch, D., \& Lawrence, G. (2005). Supermarket own brands, supply chains and the transformation of the agrofood system. International Journal of the Sociology of Agriculture and Food, 13(1), 1-18.

Butler, O. M. (1925). "Overseas trade of the Philippines". American Chamber of Commerce. September, 2-5.

Byars, A. F. (1908). Coconuts in Laguna and Tayabas provinces. The Philippine Agricultural Review, 1(12), 516-520. 
Camba, A. A. (2012). Religion, disaster, and colonial power in the Spanish Philippines in the sixteenth to seventeenth centuries. Journal for the Study of Religion, Nature \& Culture, 6(2).

Camba, A. A. (2015). From colonialism to neoliberalism: Critical reflections on Philippine mining in the "long twentieth century". The Extractive Industries and Society, 2(2), 287-301.

Campbell, C., \& Niblett, M. (2016). The Caribbean: Aesthetics, world-ecology, politics. Liverpool University Press.

Campbell, H. (2009). Breaking new ground in food regime theory: Corporate environmentalism, ecological feedbacks and 'food from somewhere' regime? Agriculture and Human Values, 26, 309-319.

Camus, J. (1921). Rice in the Philippines. The Philippine Agricultural Review, XIX. First Quarter, No. 1

Carpenter, F. G.. (1926). Through the Philippines and Hawaii (Vol. 20). Doubleday, Page.

Census of the Philippine Islands. (1905a). Taken under the direction of the Philippine Commission in the year 1903 (Vol. IIII). Washington: United States Bureau of Census.

Census of the Philippine Islands. (1905b). Taken under the direction of the Philippine Commission in the year 1903 (Vol. IV). Washington: United States Bureau of Census.

Census of the Philippine Islands. (1920). Taken under the direction of the Philippine Commission in the year 1918. Washington: United States Bureau of Census.

Cooper, F. (1928). "Can an American grow sugar cane in the Philippines"? American Chamber of Commerce. February, 21-22.

Copeland, E. B. (1908). "Spanish agricultural work in the Philippines". The Philippine Agricultural Review. August, Vol. 1, No. 1: 307-318.

Cushner, N. (1976). Landed estates in the Colonial Philippines. New Haven: Yale University Press.

Dixon, M. W. (2015). Biosecurity and the multiplication of crises in the Egyptian agri-food industry. Geoforum, 61, 90-100.

Dunaway, W. (1994). The southern fur trade and the incorporation of southern appalachia into the world-economy, 1690-1763. Review (Fernand Braudel Center), 215-242.

Eichengreen, B., \& Flandreau, M. (2012). The Federal Reserve, the Bank of England, and the rise of the dollar as an international currency, 1914-1939. Open Economies Review, 23(1), 57-87.

Elliot, C. (1916). The Philippines. To the end of the commission government. In A study in tropical democracy. Indiniapolis: The Bobs-Merrill Company Publishers.

Elser, E. E. (1925). "Fifty annual report of the president". American Chamber of Commerce. February.

Endriga, J. N. (1969). The friar lands in the Philippines during the Spanish and American regimes. University of Wisconsin-Madison.

Fairchild, G. (1921). Sugar review. The American Chamber of Commerce, August, 28.

Federici, S. (2004). Caliban and the witch: Women, the body and primitive accumulation. Brooklyn, NY: Autonomedia.

Fehr, F., \& Company. (1937, 1936). Review of the oilseed. Oil and Oil Cake Markets for, London: The Frank Fehr Brewining Company.

Fold, N., \& Pritchard, B. (2005). Cross-continental food chains. London: Routledge.

Foreman, J. (1906). The Philippine Islands: a political, geographical, ethnographical, social and commercial history of the Philippine Archipelago, embracing the whole period of Spanish rule, with an account of the succeeding American insular government (No. 23). C. Scribner's sons.

Friedmann, H. (1982). The political economy of food: The rise and fall of the post international order. American Journal of Sociology, 248-286.

Friedmann, H. (1993). The political economy of food: A global crisis. New Left Review, 29-57.

Friedmann, H., \& McMichael, P. (1989). Agriculture and the state system: The rise and decline of national agricultures, 1870 to the present. Rural Sociology, 29(2), 93-117.

Gamboa, V. (1937). "The sugar cane planter. Methods of cultivation are through". American Chamber of Commerce. April, 13.

Governor General. (1903). Report of the governor general of the Philippine Islands.

Governor General. (1908). Report of the governor general of the Philippine Islands.

Gowen, V. (1937). "Mountain farmers and the mining prospects". American Chamber of Commerce. April, 20.

Haraway. (2007). When species meet (posthumanities). Minnesota: University of Minnesota Press.

Harvey, D. (1999). The limits to capital (2nd ed.). New York: Verso.

Harvey, D. (1990). The condition of postmodernity: An enquiry into the origins cultural change. Blackwell Publishing.

Hill, P. (1925). "The rice industry". American Chamber of Commerce of the Philippines. January, 20. 
Hines, C. (1915). Sugar industry of the Philippines. In Manila. Philippines: Bureau of Printing.

Holmes, G. (1912) Wages of Farm Labor: Nineteenth Investigation, in 1909. Continuing a Series That Began in 1866. Washington, DC: U.S. Department of Agriculture, Bureau of Statistics.

Holt-Giménez, E., \& Patel, R. (2009). Food rebellions! Crisis and the hunger for justice. Oxford: Pambazuka Press.

Holt-Giménez, E., \& Shattuck, A. (2009). The agrofuels transition restructuring places and spaces in the global food system. Bulletin of Science, Technology \& Society, 29(3), 180-188.

Hribal, J. (2007). Animals, agency, and class: Writing the history of animals from below. Human Ecology Review, 14(1), 101. Hribal, J. (2011). Fear of animal planet: The hidden history of animal resistance. California: Counterpunch.

Insigne, M. (1926). "The plowman: Custodian of national wealth ignored. His self-improvement still a neglected truth". American Chamber of Commerce. January, 26-28.

Jakosalem, H., \& Reyes, F. (1922). Statistical bullet no. 4 of the Philippine Islands. (p. 1921). Bureau of Commerce and Industry: Manila. Bureau of Printing.

Jocano, F. (1987). Social organization in three Philippine villages: An exploration in rural anthropology. Quezon City: Punlad Research House, Inc.

Lava, H. (1946). "Real wages and the nation's health". American Chamber of Commerce. April, 8-9.

Legarda, B. J. (Ed.) (1999). After the galleons: Foreign trade, economic change \& entrepreneurship in the nineteenth century Philippines (Vol. 18). Madison: University of Wisconsin Center for Southeast Asian Studies.

Lohmann, L. (2006). Carbon trading: A critical conversation on climate change, privatisation and power. Dag Hammarskjöld Centre.

Luxemburg, R. (1970). The accumulation of capital. New York: Monthly Review Press.

Mandal, R. C. (2000). Coconut production and protection technology. India: Agrobios.

Mcllvaine, C. (1923). "Selecting a site for a coconut plantation in the Philippines". American Chamber of Commerce. January, 12.

McMichael, P. (2009). A food regime analysis of the 'world food crisis'. Agriculture and Human Values, 26, $281-295$.

Merritt, L. M. (1927). "Coconut shell charcoal: Possibilities". American Chamber of Commerce, May, 22.

Mies, M. (1999). Patriarchy and Accumulation on a world scale: Women in the international division of labor. London: Zed Books.

Moberly, D. (1907). Common dangerous communicable diseases of domestic animals in the Philippine Islands. The Philippine Agricultural Review, March, No. 3, Vol. 107-136.

Moore, J. W. (2000). Sugar and the expansion of the early modern world-economy: Commodity frontiers, ecological transformation, and industrialization. Review (Fernand Braudel Center), 409-433.

Moore, J. W. (2009). Madeira, sugar, and the conquest of nature in the "first" sixteenth century: Part I: From "island of timber" to sugar revolution, 1420-1506. Review (Fernand Braudel Center), 345-390.

Moore, J. W. (2015). Capitalism in the web of life: Ecology and the accumulation of capital. Verso Books.

Moore, J. W. (2017). The capitalocene, Part I: On the nature and origins of our ecological crisis. The Journal of Peasant Studies, 44(3), 594-630.

Owen, N. G. (1974). The principalia in Philippine history: Kabikolan, 1790-1898. Philippine Studies, 22(3/4), $297-324$.

Patel, R. (2009). Food sovereignty. The Journal of Peasant Studies, 36(3), 663-706.

Patel, R. (2013). The long green revolution. The Journal of Peasant Studies, 40(1), 1-63.

Peña, A. (1921). "Agricultural conditions in the Philippines 1920", in The Philippine Agricultural Review, Vol. XIV, No. 1

Phelan, J. L. (1959). Hispanization of the Philippines: Spanish aims and Filipino responses, 1565-1700. Madison: University of Wisconsin Press.

Philippine Commission. (1902a). Report of the Philippine Commission, the civil government and the heads of executive departments of the civil government of the Philippine Insular Affairs, War Department, p. 26.

Philippine Commission. (1902b). Rules and Regulations for the care, sale, etc... of certain public lands in the Philippine Islands. Messages from the President of the United States, submitting with his approval rules and regulations for the lease, sale, or other disposition of public lands, other than timber or mineral lands, in the Philippine Islands, made by the government of said islands, pursuant to the provisions of section 13 of the Act approved July 1, 1902.

Pritchard, B. (1998). The emergent contours of the third food regime: Evidence from Australian dairy and wheat sectors. Economic Geography, 74(1), 64-74.

Report of the Philippine Commission to the Secretary of War (Part 2). (1909). Report of the secretary of finance and justice. In Annual reports. War department. Washington DC: Government Printing Offices.

Robb, W. (1925a). "Motoring to Lukban: IV -- Social evolution". The American Chamber of Commerce. November, 16-18. 
Robb, W. (1925b). "Sabani estate: For rice, tobacco, sugar-Or what would you"? The American Chamber of Commerce. September, 3.

Scott, W. H. (1994). Barangay: Sixteenth-century Philippine culture and society. Ateneo University Press.

Seccombe, W. (1974). "The housewife and her labour under capitalism", New Left Review, I/83, 3-24

Shukin, N. (2009). Animal capital: Rendering life in biopolitical times. Minnesota: University of Minnesota Press.

Smith, J. (1925a). "When the Negros Province were a republic. An account by ex-governor."American Chamber of Commerce. November, 22, 26-28.

Smith, J. (1925b). "When the Negros Province were a republic. An account by ex-governor". American Chamber of Commerce. October, 8.

The American Chamber of Commerce. (1921). "Our cover page". June, 9.

The American Chamber of Commerce. (1922). "P.I sugar industry discussed from various angles". August, 23.

The American Chamber of Commerce. (1923). "New copra dryer proves successful". December, 6.

The American Chamber of Commerce. (1924). "Philippine costs compared with costs in other countries". September, 18.

The American Chamber of Commerce. (1926). "Better general quality of our copra". August, 29 \& 32.

The American Chamber of Commerce. (1932a). "American's agriculture's biggest scarecrow”. January, 18.

The American Chamber of Commerce. (1937). "Non-status sugar for army". April, 38.

The American Chamber of Commerce. (1939). "Halfway in 1939". August, 34.

The American Chamber of Commerce. (1947). "Labor". July, 81-82.

The Philippine Agricultural Review. (1908a). "The animal-disease problem," May, Vol. 1, No. 5, 188-238.

The Philippine Agricultural Review. (1912). "Report of the director of agriculture for the fiscal year ending june 30, 1911". Vol. V. No. 1.

The Philippine Agricultural Review. (1919). "Seventeenth annual report of the Bureau of Agriculture". Second Quarter, Vol. XII, No. 2: 1-106.

Waring, F. \& Dorfman, B. (1937). "Current Philippine Economics". American Chamber of Commerce. June, 1-103

Warner, B. (1939). Sugar market report (for the period Sept. 1 to Oct. 15). American Chamber of Commerce. November, 53-54.

Warren, A. (1924). "Is Philippine sugar producer building house upon sand"? American Chamber of Commerce. September, 9 , 16-19.

Weis, T. (2007). The global food economy: The battle for the future of farming. Zed Books.

Weis, T. (2013). The ecological hoofprint: The global burden of industrial livestock. New York, NY: Zed Books.

Wester. (1905). "Carabaos and Other Cattle in the Philippines", The Philippine Agricultural Review. Vol. 1.

Wester. (1920). "A review of Philippine agriculture and philippine trade opportunities in the United States", The Philippine Agricultural Review. Vol. XIII, No. 1, 5-25.

White, S. P. (1921). "Copra and its products". American Chamber of Commerce. December, 28.

Willet \& Gray. (1935). "A weekly statistical sugar trade journal". Bright Waters New York. Vol. 59.

Woodroof, J. (1979). Coconuts: Production, processing, products. United States: Avi Publication.

Youngberg, S. (1929). "Resume of the annual report of the Bureau of Agriculture for the year ending December 31, 1928", Philippine Agricultural Review, Second Quarter, No. 2, Vol. XXII, No. 2: 125.

How to cite this article: Camba AA. The food regime in late colonial Philippines: Pathways of appropriation and unpaid work. J Agrar Change. 2018;1-21. https://doi.org/10.1111/joac.12269 